\title{
Building of Academics' Networks-An analysis based on Causation and Effectuation theory
}

\author{
Rhoda Ahoba-Sam ${ }^{1}$ (D) $\cdot$ David Charles ${ }^{2}$ (ID
}

Accepted: 30 August 2019 / Published online: 17 September 2019

(C) The Author(s) 2019

\begin{abstract}
Individual academic scientists engage in various collaborations through their involvement in both regional and extra-regional networks. However, little is known about how these networks are actually formed. Focusing on university and industry networks, we take the view that the process of building new networks is an entrepreneurial activity that involves unpredictability and often goal ambiguity. This paper thus employs the theories of causation and effectuation to explore how the personal networks of academics are initiated. With evidence from the networks of 12 academics based at the University of Stavanger, Norway we show that both causation and effectuation are employed by academics when building their networks. The usage of causation was found to be more consistent with building industry networks whereas effectuation was employed when building networks in academia. Consequently, effectuation was characteristic of the international networks which were found to be mostly constituted by other academics. On the regional level, a mixture of both approaches of causation and effectuation was observed, with more industry linkages suggesting a tendency to be more causal than effectual. Furthermore, while causation was employed for project level networking, effectuation was employed for establishing more individual level ties.
\end{abstract}

Keywords Academic scientists · Effectuation - Causation · Networking · Industry · Academia - University of Stavanger

JEL Codes D81 $\cdot$ D85 $\cdot$ D91 $\cdot$ I23

R. Ahoba-Sam

rahobasam@lincoln.ac.uk

1 Lincoln International Business School, University of Lincoln, Lincoln, UK

2 Newcastle Business School, Northumbria University, Newcastle, UK 


\section{Introduction}

Governments for many years have been keen to encourage University-Industry Collaborations (UICs). This is particularly so in those regions with a poor performance on innovation (Charles 2006). It has been acknowledged that through knowledge-based collaborations for instance, universities can assist firms in bringing forward technological innovations in their regions (Sternberg 2000; Gunasekara 2006; Agrawal 2001; Charles 2006). In Norway, as in many European countries, various reforms have increasingly led to the diminishing of the perceived boundaries between universities and their environment (Sataøen 2018). By forging new and closer local relationships, universities contribute to the social and economic development of their regions (Trippl et al. 2012; Charles 2006; Christopherson and Clark 2010).

In the pursuance of an additional or 'third' role of outreach activities that aims to contribute to innovation and social change (Gulbrandsen and Slipersæter 2007), universities have adopted varying models. For example, some universities have assumed the role of an 'entrepreneurial' university (Foss and Gibson 2015). In such universities an increased emphasis is placed on commercializing research, licensing of technology, creating university spin-offs, introducing entrepreneurship programmes, and expanding university-industry relationships (Foss and Gibson 2015; Klofsten and Jones-Evans 2000; Altmann and Ebersberger 2013; Clark 1998). Beyond this, there is an expectation that academics take on entrepreneurial characteristics within an entrepreneurial culture (Vorley and Nelles 2009). Etzkowitz (2003), illustrates these entrepreneurial traits at the sub-organisational level where research groups are described to function as 'quasi' firms.

Several studies have developed entrepreneurial profiles of academic scientists depending on the specific engagement mode identified. 'Academic Entrepreneurs' are those academics looking to commercialise academic intellectual property-these academics essentially act as entrepreneurs. On the other hand, 'Entrepreneurial Academics' are those academics who act entrepreneurially in order to accomplish their academic jobs (Miller et al. 2018; Nyeko and Sing 2015; Jain et al. 2009; Meyer 2003). These profiles encompass teaching and building of entrepreneurial competency as well as creating new ventures. Indeed, academic entrepreneurship is conceptualised as encompassing a wider range of engagement activities than only commercialisation (Jain et al. 2009). Further, academic scientists have been shown to form linkages across university and industry entities for the purpose of accessing and disseminating knowledge (Lam 2007; Stuck et al. 2016; Pataraia et al. 2014, 2015; Lowrie and McKnight 2004) underpinned by social networks (Granovetter 1973).

Engel et al. (2017) posit that the process of building new networks by entrepreneurs is a form of entrepreneurial activity that involves unpredictability and often, goal ambiguity. Following from the increasing entrepreneurial identity assumed by academics, we compare the decision-making process of entrepreneurial academics to that of traditional entrepreneurs. We specifically theorise that the actions of individual academics, when the outcomes of networking cannot be identified in advance, are comparable to the decision-making approaches employed by traditional entrepreneurs faced by uncertainty. The theories of effectuation (i.e. flexible 
and non-goal directed decision-making) and causation (i.e. goal-directed decisionmaking) (Sarasvathy 2005 2001; Sarasvathy and Dew 2011; Engel et al. 2017) can thus be employed to explore how networks of academics develop.

Knowing the approach employed by academics is key to understanding the possible outcomes of their social networks with respect to opportunity discovery (Sarasvathy 2005). Simply, by employing the entrepreneurial theories of causation and effectuation, we contribute to a potentially under-researched aspect of the literature on how academics build their networks. Subsequently, we also explore how the approach employed relates to the type of tie (i.e. industry or academia) to be established and the geography of those networks. Evidence was collected through in-depth interviews with academics from the University of Stavanger (UiS), Norway-a university with a history of co-evolution with the oil-industry, the major industry in its region.

\section{Literature Review and conceptual Framework}

Academic scientists advance their research through networks of multidisciplinary individuals (Stuck et al. 2016; Henry and Pinch 2000; Perkmann and Walsh 2007). For instance, academics engage with industry or government agencies (Ramos-Vielba et al. 2016), and network for the purpose of exchanging knowledge (Lam 2007; Stuck et al. 2016; Pataraia et al. 2014, 2015; Lowrie and McKnight 2004). Fernández-Pérez et al. (2015) have reported that academic scientists are important for both the dissemination of new knowledge and identifying opportunities through which knowledge could be converted into commercial form (Perkmann et al. 2011). Consequently, their experience also makes these academics likely partners for companies seeking to commercialise acquired knowledge (Siegel et al. 2007). These networks involving academics exist at both regional and extra-regional levels (Trippl 2013; Mahroum 2000).

Various modes of engagement employed by universities are largely policy-driven (Sataøen 2018). Universities have been increasingly encouraged by governments to actively participate in regional development (Charles 2006). Some universities have assumed an entrepreneurial model (Gulbrandsen and Slipersæter 2007; Foss and Gibson 2015), and their role in the generation and dissemination of information is perceived to have both tangible and intangible benefits (Shaw and Allison 1999; Goddard and Chatterton 1999; Vorley and Nelles 2009). At the regional level for instance, universities are involved in innovative projects that enhance the competitiveness of regional firms. These knowledge exchange projects comprise part of the 'third mission' role, which highlights the engagement of universities with their communities outside traditional research and teaching roles. Consequently, the boundaries between universities and communities have diminished (Sataøen 2018).

Given the key role of individual actors in knowledge exchange processes (Henry and Pinch 2000; Nonaka 1994; Almeida and Kogut 1999), individual academics have been reported to also assume entrepreneurial roles. These roles encompass teaching and building of entrepreneurial competency as well as creating new ventures. Academic entrepreneurship is conceptualised as encompassing a wider range 
Table 1 Entrepreneurial Profiles of Academic Scientists. (Source: Authors' own emphasis after Miller et al. 2018)

\begin{tabular}{|c|c|}
\hline Academic & Related entrepreneurial activities \\
\hline $\begin{array}{l}\text { Academic en- } \\
\text { trepreneur } \\
\text { (more formal, } \\
\text { transactional, con- } \\
\text { tracting-style en- } \\
\text { gagement) }\end{array}$ & $\begin{array}{l}\text { 1. Contract research and consultancy for industry } \\
\text { 2. Partnering with industry to invest in developing and operating equipment or } \\
\text { a facility } \\
\text { 3. Joint ventures with industry (without creation of a new company) } \\
\text { 4. Contributing to the formation of one or more new spin-off companies } \\
\text { 5. Patenting and licensing of knowledge or know-how together with a commer- } \\
\text { cial partner }\end{array}$ \\
\hline $\begin{array}{l}\text { Entrepreneurial } \\
\text { academic } \\
\text { (informal, rela- } \\
\text { tional, partnering- } \\
\text { style engagement) }\end{array}$ & $\begin{array}{l}\text { 1. Collaborative research with commercial and academic partners for problem- } \\
\text { solving or developing new knowledge } \\
\text { 2. Joint supervision of research together with industrialists } \\
\text { 3. Research-based consultancy for industry through the university } \\
\text { 4. Conduct education/teaching for commercial partners on new developments to } \\
\text { bridge their professional knowledge gap } \\
\text { 5. Involvement in industrial secondments, student placements and graduate em- } \\
\text { ployment }\end{array}$ \\
\hline
\end{tabular}

of engagement activities than only commercialisation (Jain et al. 2009). Accordingly, efforts that encourage the building of entrepreneurial capacities within universities are also considered entrepreneurial (Klofsten and Jones-Evans 2000; Altmann and Ebersberger 2013). To the extent that research groups within universities have been described to function as 'quasi' firms (Etzkowitz 2003), it can be inferred that academics may act in an entrepreneurial manner when pursuing the development of research networks and building research teams.

The entrepreneurial profiles assumed by academics cover a host of engagement activities, as shown in Table 1. Opposed to the classical commercial 'academic entrepreneur', the 'entrepreneurial academic' adapts an entrepreneurial outlook and pursues industry partnerships with the aim to further their research objectives (Jain et al. 2009; Miller et al. 2018). While the academic entrepreneur pursues more formal partnerships with commercialisation partners, the entrepreneurial academic engages with commercial partners in a range of collaborative and less formal modes of engagement. These entrepreneurial traits adopted by academics are mostly related to teaching, administration or consulting (Nyeko and Sing 2015; Jain et al. 2009; Perkmann et al. 2013; Miller et al. 2018).

Effectuation theory, with its focus on non-goal driven logic, improvisation and leveraging contingencies (Sarasvathy 2005, 2001), has great potential to explain the undirected aspect of networking (Engel et al. 2017). Expert entrepreneurs make decisions in a non-predictive manner by employing five principles, characterised as: bird-in-hand, affordable loss, lemonade, patchwork quilt and pilot-in-the-plane (Sarasvathy 2005) as elaborated in Table 2. Causation, in contrast to effectuation rests on the logic of prediction and demands that the entrepreneur makes an analysis of the future on the basis of which a decision can be made, i.e. where knowledge thrives. The logic for using the causation processes is, to the extent that we foresee the future, we can control it whereas that for effectuation is, to the extent that we can work with things within our control, we don't need to predict the future (Sarasvathy 2001). 
Table 2 Emphasizing the principles of Effectuation. (Source: Own emphasis based on Sarasvathy 2005, 2001)

\begin{tabular}{|c|c|c|}
\hline Principle & Effectuation & Causation \\
\hline $\begin{array}{l}\text { Bird-in- } \\
\text { hand }\end{array}$ & $\begin{array}{l}\text { Create opportunities and perform actions based on the } \\
\text { resources available here and now; i.e. who you are, what } \\
\text { you know and whom you know }\end{array}$ & $\begin{array}{l}\text { Have a predetermined } \\
\text { goal or a pre-envisioned } \\
\text { opportunity }\end{array}$ \\
\hline $\begin{array}{l}\text { Affordable } \\
\text { loss }\end{array}$ & You should only invest what you are willing to lose & $\begin{array}{l}\text { Venture must maximise } \\
\text { risk-adjusted return }\end{array}$ \\
\hline Lemonade & $\begin{array}{l}\text { Mistakes and surprises are inevitable and can be used to } \\
\text { look for new opportunities }\end{array}$ & $\begin{array}{l}\text { Planning and focusing } \\
\text { on goals help to avoid } \\
\text { contingencies }\end{array}$ \\
\hline $\begin{array}{l}\text { Patchwork } \\
\text { quilt }\end{array}$ & $\begin{array}{l}\text { Entering into new partnerships can bring the project new } \\
\text { funds and new directions }\end{array}$ & $\begin{array}{l}\text { Focus on competitors } \\
\text { rather than partnerships }\end{array}$ \\
\hline $\begin{array}{l}\text { Pilot-in- } \\
\text { the-plane }\end{array}$ & $\begin{array}{l}\text { Co-create the future with things within your control and } \\
\text { with self-selected partners }\end{array}$ & $\begin{array}{l}\text { Future environment is } \\
\text { given, forecasts help to } \\
\text { adapt to it }\end{array}$ \\
\hline
\end{tabular}

The effectual and causal approaches adopted while networking have been operationalised as elaborated in Table 3. Causation employs a goal-directed approach whereas effectuation employs an emergent and unordered approach focused on cocreation (Sarasvathy 2005). Causal thinkers intend from the outset to achieve a specific goal while effectuators leverage the effect of circumstances and unexpected surprises while networking (Engel et al. 2017; Sarasvathy 2005). While effectual thinkers may not have a specific purpose for establishing a network, causators approach networking by taking deliberate actions concerning who to collaborate with and what needs to be achieved (Engel et al. 2017).

While not being goal-specific, effectuators have a broader perspective of networking and objectives in mind. The focus is placed on generating unexpected contingencies through meeting new people and discovering new facets in existing ties. Typically, effectual thinkers pursue goals based on an assessment of what is already available within their means following the 'bird-in-hand' principle (Sarasvathy 2005). Effectuators do not pursue random interests but what they consider to be worthwhile. In contrast, a narrow approach employed by causators is focused on meeting the right people and reaching them efficiently (Engel et al. 2017).

It has been suggested that entrepreneurs are able to shift between the use of effectuation and causation (Schreier and Senn 2018; Andersson 2011). The effectual approach to network-building has been explained to be positively associated with initial entry speed and international scope speed while a causal approach is negatively associated with initial entry speed and international scope speed (Prashantham et al. 2019). Galkina and Chetty (2015) also show that entrepreneurs of small and medium enterprises network with interested partners, instead of carefully selecting international partners according to predefined network goals. In the case of opportunity recognition it has been further highlighted that self-efficacy, entrepreneurial cognitive activities and access to specific resources (means at hand) are determinants for international new ventures to materialize (Hannibal et al. 2016; Andersson and Evers 2015). These studies show that both endogenous and exogenous factors influence the usage of either effectuation or causation. 
Table 3 Contrasting goal-directed and effectual networking. (Source: Adapted from Engel et al. 2017)

\begin{tabular}{|c|c|c|}
\hline & Effectual networking & Causal networking \\
\hline $\begin{array}{l}\text { Venture } \\
\text { objectives } \\
\text { are }\end{array}$ & $\begin{array}{l}\text { Emergent, flexible, and unordered (i.e., } \\
\text { networking determines venture goals } \\
\text { through co-creation) }\end{array}$ & $\begin{array}{l}\text { Given and fixed, preferences are clearly } \\
\text { ordered (i.e., venture goals determine } \\
\text { networking goals) }\end{array}$ \\
\hline $\begin{array}{l}\text { Networking } \\
\text { objectives } \\
\text { are }\end{array}$ & $\begin{array}{l}\text { Not available and in some cases not know- } \\
\text { able (i.e., uncertainty) }\end{array}$ & $\begin{array}{l}\text { Available to some extent but largely } \\
\text { unpredictable (i.e., risk) }\end{array}$ \\
\hline $\begin{array}{l}\text { Networking } \\
\text { is motivated } \\
\text { by }\end{array}$ & $\begin{array}{l}\text { Both self- and collective interests with } \\
\text { predominantly developmental motives } \\
\text { (e.g., "what can we do together?") }\end{array}$ & $\begin{array}{l}\text { Rational self-interest with predominantly } \\
\text { instrumental motives (e.g., "what can I } \\
\text { get from you?") }\end{array}$ \\
\hline $\begin{array}{l}\text { Networking } \\
\text { begins with }\end{array}$ & $\begin{array}{l}\text { Existing and predominantly strong ties } \\
\text { (as part of initial assessment of currently } \\
\text { available means within the network) }\end{array}$ & $\begin{array}{l}\text { Both new and existing ties, whether they } \\
\text { are weak or strong (as part of resource } \\
\text { seeking activities to satisfy projected } \\
\text { future needs) }\end{array}$ \\
\hline $\begin{array}{l}\text { Networking } \\
\text { search } \\
\text { scope is }\end{array}$ & $\begin{array}{l}\text { Broad, directed at generating unexpected } \\
\text { contingencies (i.e., focused on meeting } \\
\text { new people or discovering new facets in } \\
\text { existing ties) }\end{array}$ & $\begin{array}{l}\text { Narrow, directed at specific predeter- } \\
\text { mined targets (i.e., focused on meeting } \\
\text { the "right" people and reaching them } \\
\text { efficiently) }\end{array}$ \\
\hline $\begin{array}{l}\text { Tie interac- } \\
\text { tion is }\end{array}$ & $\begin{array}{l}\text { Primarily based on intelligent altruism and } \\
\text { relational embedding (i.e., "if I commit } \\
\text { to help others, they are more likely to } \\
\text { reciprocate") }\end{array}$ & $\begin{array}{l}\text { Primarily calculative and transactional } \\
\text { (i.e., "how should I protect myself from } \\
\text { opportunistic behaviour of others?") }\end{array}$ \\
\hline $\begin{array}{l}\text { Tie selec- } \\
\text { tion is }\end{array}$ & $\begin{array}{l}\text { Based on self-selection (ties self-select } \\
\text { based on what they can afford to commit } \\
\text { in advance) }\end{array}$ & $\begin{array}{l}\text { Based on given objectives (ties are se- } \\
\text { lected for their future expected value) }\end{array}$ \\
\hline $\begin{array}{l}\text { Eventual } \\
\text { network } \\
\text { change } \\
\text { leads to }\end{array}$ & $\begin{array}{l}\text { Serendipitous outcomes involving re- } \\
\text { sources, ideas, or both, which result in } \\
\text { new or modified venture goals }\end{array}$ & $\begin{array}{l}\text { Securing needed resources and progress- } \\
\text { ing toward given venture goals }\end{array}$ \\
\hline
\end{tabular}

The concept of causation and effectuation fit well with the concepts of exploitation and exploration described by (March 1991). Sarasvathy (2005) highlights this by explaining the causal approach of exploiting pre-existing knowledge as opposed to the effectual tendency to explore new ideas. While the returns of exploitation are usually positive, proximate, and predictable, the essence of exploration is experimentation with new alternatives (March 1991). This implies that exploitation, because it is action based on existing facts, most likely yields expected outcomes. In contrast, exploration results in unexpected and serendipitous outcomes.

\section{Methodology and case study description}

In this study, the extent to which individual academics employ causation or effectuation when building their networks was assessed. Particular focus was placed on individual network contacts and how these links were initiated. The social network approach to building ego networks was loosely applied for obtaining specific examples in order to examine the development of academic networks. Subsequently, the 
theories of effectuation and causation were applied according to the characteristics of the two approaches as shown in Table 2.

When building ego networks via the personal network design approach, three distinct steps are involved; 1 . Generation of names of contacts (alters) based on simple open-ended questions, 2. Interpretation of names where the respondent is asked about each name mentioned and 3. Name Interrelation, where the respondent is asked about the ties between alters. However, it is not required that a network be connected nor to have any ties at all especially at its initiation (Borgatti et al. 2013). For this reason, it is possible to have an ego network without necessarily emphasizing the connections between them. Accordingly, the third step of "name interrelation' is omitted here, as connections between alters is not a question for this study which focused on the initiation of the Academics' networks.

The university and regional contexts were both of importance for this study-the University of Stavanger presented an interesting case. The university was established at least in part in response to the discovery of oil offshore from the region of Rogaland and subsequently co-evolved with the development of the oil industry. Together, the discovery of oil and the subsequent establishment of the UiS have contributed to the economic and social transformation of the region (Ahoba-Sam 2019; Alpaydin et al. 2018).

It was expedient to select from a population of academics who were known to be engaged with industry. Consequently, we focused on engineering and applied sciences as these disciplines have been shown to report high levels of industry engagement (Perkmann et al. 2013). The data presented here reflects the views of selected academics from the Engineering Faculty of the University of Stavanger (UiS), Norway. The selected academics were specifically from the Centre for Risk Management and Societal Safety (SEROS), and the departments of Electrical Engineering and Computer Science, Energy and Petroleum Engineering, Mathematics and Physics, and Energy Resources of the UiS Engineering faculty.

Evidence was collected through in-depth questioning of 12 selected academic scientists during the period of March-May 2018. Interviews averaged about one hour and were recorded with the permission of interviewees. In the interviews, about 10 individual network contacts were discussed for each of the 12 interviewees. This made it possible to assess how a single individual established different ties. Specifically, each interviewee was engaged in an interactive session where they were asked to write down 10 of their 'important' network contacts ${ }^{1}$. This resulted in the provision of 8-12 names each from interviewees. In this way, 118 observations were obtained and analysed. The definition of importance was left to each interviewee's discretion. After generating this list, we proceeded to discuss each of the individuals' contacts in light of how they were initiated, and the peculiarities of each relationship examined.

The interviews were recorded with the permission of the interviewees and subsequently transcribed. Coding essentially took three steps. In the first instance, the emerging themes were identified as expressed in the interviewees' own words. Next, these themes were grouped across the various interviews in view of the suggested

\footnotetext{
1 See Appendix, Table 4 used to generate the list of network contacts.
} 
networking categories Engel et al. (2017) suggest as shown in Table 3. Next these emergent codes are weaved together to tell the lessons discovered, buttressed by interviewees' quotes.

Interviews were conducted in the period March-May 2018. All interviewees were of post-graduate level and aged between 35-65 years. Four were women, with the remaining 8 being men. 3 of them were of expatriate origin whereas 9 were Norwegians. The academic scientists were selected non-purposefully, based on references obtained from the central administration of the UiS. From a list containing 204 academics known by the University to be externally engaged, a selection was made based on on-going industry projects under the faculty of engineering $(\sim 67)$. From a total of 15 engaged academics who accepted to be interviewed, only the 12 interviewees ${ }^{2}$ represented here consented to sharing specific examples of their personal network contacts. Overall, the questions discussed were focused on understanding how the academics' networks were established. The data collected was transcribed and subsequently coded in order to identify common themes and patterns for analysis (Yin 1984).

A qualitative approach was employed, which presents the advantage of understanding the complexity of UICs especially as each collaboration is unique (Plewa et al. 2013). The semi-structured nature of interviews was useful for obtaining indepth understanding of the cases reviewed (Yin 2002; Hammarberg et al. 2016; Wilson 2014). All interviewees are anonymized and will also be referred to as Interviewee A1, A2, ... to A12. Further, since the data collected is personal, the names of contacts and further information leading to the possible identification of persons are excluded.

\section{Results and Analysis}

This section reviews the general nature of the networks of the individual academics analysed in this study. Since 118 observation points have been made, we therefore first present some general description of the collected data. Next, details on the approaches employed to build the academics' networks are presented in line with the dimensions presented in Table $2 .^{3}$

\subsection{General description of networks}

As shown in Fig. 1, the largest group of personal contacts identified were other academics at $45 \%$ with industry contacts taking second place at $33 \%$. Research institutes and other forms of contact made up the remaining $22 \%$.

Further, these networks included regional (33\%), national (17\%) and international $(51 \%)$ ties for university-industry linkages as shown in Fig. 2. Focusing only on university and industry linkages, it was observed that $64 \%$ of the international ties

\footnotetext{
2 Excerpts from these interviews are also included in the paper Ahoba-Sam (2019).

3 Table 5 in the Appendix shows a classification of the main entrepreneurial activities observed for the interviewees based on Table 1.
} 
Fig. 1 Constitution of Academics' Networks

Fig. 2 Geographical distribution of collaborators
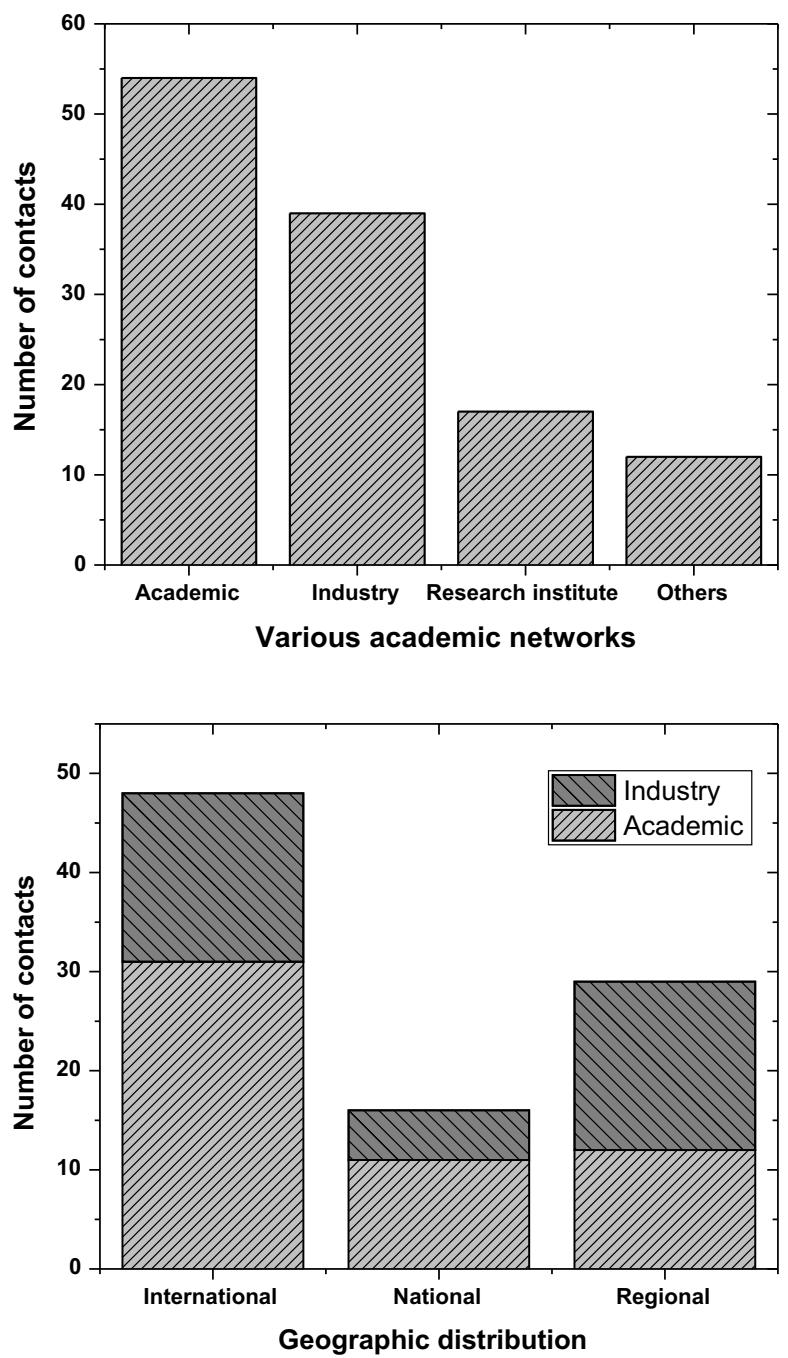

were with other academics whereas the remaining $35 \%$ were industry ties. For the regional networks, $41 \%$ were academics whereas the remaining $58 \%$ were industry links. At the national level, more academic contacts $(68 \%)$ were observed than industry contacts $(31 \%)$ indicating a similar trend as the international level. Almost all the academics mentioned network contacts ${ }^{4}$ across the different geographical levels assessed (except for interviewees A1 and A11 who mentioned no national contacts, and A2 who mentioned no regional contacts).

The number of industry linkages observed were similar for both the international and regional levels at $18 \%$ each. International linkages on the other hand were

\footnotetext{
${ }^{4}$ See Table 6 in the Appendix for details on the distribution (organisational and geographic) of network contacts.
} 
found to usually be with other academics at 33\% (as highlighted in the cases of interviewees A4, A5, A6, A8, A9, A10, A11 and A12). In explaining the choice of an international academic tie, interviewee A4 explained, 'there are very few people in Norway who can do what I am doing or even locally here in Stavanger, so I have had to go international to get the best'

Another interesting trend was that for most industry ties, linkages were not solely related to the individual in question but were made due to the need to have a contact person with a specific firm (as highlighted in the case of interviewees A1, A3, A4, A8, A9, A11 and A12). As the industry projects progressed, new ties were by necessity established within the same firm with changing employee roles. In contrast, ties in academia were made at a more individual level as highlighted by interviewee A3, 'within academia, it is more or less linked to the individual person and their knowledge'. Consequently, more project level ties were identified for industry networks.

\subsection{Contrasting causal and effectual networking}

\subsubsection{Venture and networking Objectives}

Both effectual and causal approaches were employed by all the interviewees for setting objectives for networking. It was however evident that the approach employed depended heavily on whether the prospective linkage was to be made on the individual or project level. For instance, interviewee A2 explained that for embarking on projects involving industry, there was a need to prepare a proposal, 'Yeah for some projects you have to send a proposal and they have to agree on that'. Further, singling out networking specific to industry, Interviewee A1 added that 'for the industry side, you need to have a project idea that you know is an industry need'. These suggest a causal approach of having fixed and ordered goals in place prior to the actual networking.

On the individual level, a more effectual approach was observed for setting networking objectives. As indicated by A4, 'I meet them at conferences sometimes and we sit to have a cup of coffee, we chat a bit and we discuss the latest things happening in our research areas ... and we might get together and brainstorm once a year. And I might send them a mail about [hey] have you seen this research paper? Or I have got some results I don't quite understand ... do you mind, what do you think? You know? Or do you have any research money available for doing this? Those are the things that happen'. This was also reiterated by interviewees A6 and A11 as an approach consistent with networking with other academics rather than with industry.

As the network became more established however, more focus was introduced towards objective setting as exemplified in the following: A2: 'later on I think you are more focused on getting projects which are relevant and making them into publications'. Additionally interviewee A4 explained, 'I am quite conscious about trying to get the goals or purpose of the project and doing everything correctly ... I don't want to waste the collaboration in a sense'. 


\subsubsection{Networking Motivation}

None of the interviewees' exhibited a purely causal mind-set for networking with other academic partners. For example, in line with an effectual mind set interviewee A11 explained that, 'I have to establish that I can contribute in the project with my experience and knowledge'. This implied that being able to contribute with their own knowledge is an important factor when building networks on the project level which emphasizes the bird-in-hand principle.

Further, the focus was on the ability to build something together capitalising on both self and collective interests. Interviewee A4 explained about establishing a network with an international academic as follows; 'I am a chemist and I do know how to make a lot of chemicals but I don't always have the best equipment for it, so actually I read a lot of literature. And this guy ' $X$ ' I have just mentioned, months ago I just read one of his papers and ... I wrote him and said do you mind sending me a sample and we will test it and do a joint paper together if it looks interesting and he said sure'. Additionally, interviewee A2 explained that, 'I think you often make collaborations between colleagues, so if you are joining a project you can work together on issues and have common papers with them'

Further where networking was in order to obtain access to funding of their research projects it appeared that a more causal approach was employed. This was explained by interviewee A9, "whenever there is money involved, there is a report due ...' Further, concerning industry in particular, interviewee A2 explained, 'they (industry) are more selective of what kind of projects they are running and often, short time projects with short perspective because that is what is paying back'. By these it was understood that the causal approach was also utilised as a means to meet an external requirement rather than it being a personal orientation or approach.

\subsubsection{Networking situation, Interactions \& Selections}

Of the interviewed academics, interviewees A1, A4 and A6 were expatriates working in the UiS and had to establish their local/regional networks from scratch. A deliberate effort towards setting up of a local network was therefore necessary in integrating themselves into the local community at the initial stages. According to A1 for instance on building his local network, 'you know it's like anything else when you move to a new country, you need to start making friends and neighbours, and that takes time so, at that time, my network was very limited ... I took my PowerPoint, took my bike went and visited companies ... it was kind of a new territory so that took a while to build up'.

Concerning specific projects pitched to companies, A1 also made a comment consistent with effectual reasoning: 'we talked about what the project is, probably more questions than answers a lot of naivety but you know people were interested'. As the project progressed however, there was the need to assume a more causal approach to ensure a selection of the right ties; A1: 'I may have some contacts from my standing point of view and then you try to bring them on board when there is an expertise' 


\subsubsection{Networking Search scope}

Among the interviewees, a mixture of effectuation and causation was employed relating to the networking search scope. On one hand, the approach was narrow and directed, focused on meeting the right people. As stated by interviewee A3, 'I could collaborate with other people at the university here but if they don't have any chemical knowledge, why should I collaborate with them? They will just slow me down most likely. They just want me to contribute but they are not able to contribute to improvement for my own research. So, in a way you have to choose your friends.' In this case, interviewee A3 explained that the absence of colleagues who were equally knowledgeable in his specific research area influenced his decision to seek international scholars who fit a certain useful profile for his research activities.

Interviewee A1 explained that the requirements of certain projects indirectly dictated the scope of networking search; 'the project at the moment is the budget design, so everything at the moment boils down to economics. So, to start this project we need 3 companies ... right, so we start in-house, if we get more companies, the project can grow ... so which companies are we interested in?' Further interviewee A3 explained with regards to national funding requirements and the influence they have on the search scope as follows; "if I have a funding from someone ... from the Norwegian research council or from others, they would like me to have a collaboration but they don't like me to spend money overseas'

\subsubsection{Outcome of Network Change}

In accordance with effectual networking, eventual network change leads to serendipitous outcomes resulting in modified venture goals. Networking resulted in publications, access to infrastructure for students' practical work as highlighted in the cases of interviewees A1, A4, A6, A7, A8, A9, A11 and A12. As explicitly explained by interviewee A6 referring to an international educational network, 'So we started from just having a little exchange of small dialogue about meeting in conferences and we see what we can do together for these educational projects, research projects ... now we have students going up and down. So that was very good ...'

It was also interesting to find an example highlighting how further network ties emerge out of industry projects. As in the case of interviewee A7, 'when you have meetings with people in industry on one project, then you meet others from other companies coming in ... you talk to them and then you expand your network'. This implies that while industry networks have been explained to be more goal directed, they could span other ties that have no initial network objectives.

On the other hand, causal networking led to securing needed resources and progressing toward given venture goals. Interviewee A1 explained about an industry project that emerged from a previous one, 'we created a new project ... the [previous] project became smaller and it became a different focus. So it is basically a continuation of this ... but it doesn't mean we are touching all the topics that we were aiming to ... it's now more specific topics but in the oil industry case, these have decreased, and we didn't need all of the [previous] expertise anymore. So we are just pointing to people' 
Academics were observed to switch between being causal or effectual when building their network ties. Causation was found to be consistent with project level ties where goals of networking needed to be fixed or clearly ordered from the beginning. On the individual level however, a more effectual approach was observed. Here, there was no need to have already focused ideas prior to networking. This approach of effectuation was also consistent with ties established with other academics on the individual level. When operating in project mode, whether networking with academics or industry contacts, a more causal approach was observed.

\section{Discussion and Conclusions}

This study has shown that academic scientists use both effectuation and causation to build their networks. It has revealed the application of opportunity exploration and exploitation tendencies when initiating contacts across geographical (regional or international) and institutional (industry or academia) types. In a related study, AhobaSam (2019) shows that the motivations for these academic scientists to collaborate are mediated by both personal and external factors. Similarly, the approach (i.e. causation or effectuation) employed by the academics studied was observed to be affected by both endogenous and exogenous factors. The choice of which approach to use was not necessarily always dependent on the academic's personal preference. It was evident that external pressures such as the requirements of funding bodies were likely to influence a causal approach in networking rather than a more effectual approach. To this end, causation was observed more with industry networking. It can be inferred that the choice of which approach to employ is also linked to the motivation to network-if the initiation of the network is externally motivated (e.g. to access funding), there is the likelihood to employ a causal approach rather than if it is a personal motivation such as exchanging research ideas with another academic with less instrumental objectives.

The findings of this study offer some evidential support to the propositions made by Engel et al. (2017) about entrepreneurial networking. Engel et al.'s (2017, p. 44) proposition 1 states that, 'under uncertainty entrepreneurial networking is driven by an assessment of available means within the network as carried out through repeated interactions with both existing and new network ties'. It is evident in this study that the academics' networking was driven by the means at hand especially with regards to their competences and capabilities prior to embarking on various collaborations. However, because the focus of this study has been on the initiation stages of the networks analysed, whether they used 'existing or new' ties was not evident-suffice to say, in this study each network tie was analysed as if new.

Proposition 2 by Engel et al. (2017) states that, 'under uncertainty, negotiations over pre-commitments are informed by entrepreneurs' networking actions as driven by both collective and self-interest and as restricted by a predetermined level of affordable loss'. This was also evident in our study given that the academics' focus was on the ability to build something together capitalising on both self and collective interests. Proposition 3 states that 'under uncertainty, effectual networking changes the portfolio of ties who commit to co-create the venture, thereby gener- 
ating unexpected contingencies and enabling the serendipitous emergence of new entrepreneurial goals' (Engel et al. 2017, p. 47). This was also evident in the data with effectual approaches leading to exploration of new ideas. Though not explored in this study, it was suggested that as the network evolved, the tendency to be causal was more prominent as more intentional and directed decisions were made.

To the extent that most of the international networks of academics are with other academic scientists, effectuation was apparent. These networks were usually explorative in nature where intersections in research interests were sought between collaborating academics to explore new ideas (Sarasvathy 2005; March 1991). On the regional level, a mixture of the two approaches were observed. With the balance of collaborators tilted more to the industry side, a higher tendency to employ a causal approach to exploit opportunities for enhancing academics' research objectives was observed.

The usage of a more causal approach at the regional level has some implications, and may mitigate the potentials of UICs. Whereas a causal approach to networking is projected to lead to securing the needed resources for achieving given venture goals, effectual approaches lead to more serendipitous outcomes that result in new or modified goals (Engel et al. 2017). The contributions of universities to regional innovation may be mitigated if regional networks assume a purely causal form. For the purpose of regional innovation it would appear that effectual processes that promote more emergent and unordered networking approaches focused on co-creation (Sarasvathy 2005) need to be encouraged. This is important for leveraging the effect of circumstances and unexpected surprises when networking (Engel et al. 2017) and would allow for identification of new ideas and opportunities. For the specific case of oil-rich Stavanger, more effectual processes that promote serendipitous outcomes involving resources and ideas are key to exploring new paths relevant for the oil industry.

Contrary to the finding by Schreier and Senn (2018) on expatriate entrepreneurs, the expatriate academics mostly employed a causal approach for building their industry networks. This was especially the case as proposals and research ideas were needed to get industry interested in academics' work having moved into new territory. While describing how their various networks were initiated however, it was evident that neither causation nor effectuation were consistent with the initiation stages of a tie. It all depended on differing factors such as the type of tie (i.e. industry or academia) and at what level the tie was being initiated (i.e. project level or individual level). Further, the swap between the two reasoning approaches was portrayed in a non-linear fashion. For example, a tie could start off as effectual and become more causal when the research objectives were decided, but once objectives were achieved it was possible to revert to the more explorative approach consistent with effectual reasoning for finding additional areas to research.

As evidenced from this study, academic scientists exhibited an ambidextrous capacity to swap between effectuation and causation depending on the particular circumstance. This capacity seems to have been necessitated by the heterogeneous makeup of their network ties, being: level of ties (individual or project-based), type of ties (industry or academic) and geography of ties (local or international). We argue that, in so far as academic networks exhibit heterogeneous characteristics (of 
the nature of ties formed), the greater the need to possess and exhibit the ability to swap between causal and effectual tendencies. This adaptability enables academic scientists to initiate and maintain ties with different contacts.

While the study contributes to the existing literature, it is case-specific and the generalizability of the findings reported here is limited. Because this study has focused on a single case university and faculty, the networking approaches reported may not be fully representative of academics in a wider range of contexts and settings. After all, the decision to exploit an opportunity is very individual-specific (Venkataraman 1997; Hayek 1945). It would also have been worth exploring the possibility to link these findings to the wider network structure, in order to explore what happens in a dense or sparse network. A comparison between the usage of causation and effectuation and network evolution would also shed some useful insights-further research could focus on unearthing these.

A next step would be to compare the reported findings with other groups of academics from different contexts (e.g. academic backgrounds and countries). Selecting cases from different regional settings would also be important for examining the effect of the regional context on the approach taken by academics when networking. Further, because of the strong linkages of UiS to the oil industry, most of the academics' industry networks were linked to oil firms. Would different types of firms impose a different kind of effect on the choice between effectuation and causation? Future research could thus focus on obtaining a broader range of evidence based on different contexts.

Acknowledgements We are grateful to Prof. Thomas Brenner, Prof. Daniel Schiller and two anonymous reviewers for their constructive feedback on earlier versions of this paper. Errors and omissions remain the responsibility of the authors.

Open Access This article is distributed under the terms of the Creative Commons Attribution 4.0 International License (http://creativecommons.org/licenses/by/4.0/), which permits unrestricted use, distribution, and reproduction in any medium, provided you give appropriate credit to the original author(s) and the source, provide a link to the Creative Commons license, and indicate if changes were made.

Funding This study was supported by the European Union's Horizon 2020 research and innovation programme under Marie Sklodowska-Curie grant agreement No. 722295. 


\section{Appendix}

Table 4 Table for ego-network analysis

\begin{tabular}{lll}
\hline Name (or pseudonym) & Geography & Academia/industry \\
\hline 1 & $\ldots$ & $\ldots$ \\
2 & $\ldots$ & $\ldots$ \\
3 & $\ldots$ & $\ldots$ \\
4 & $\ldots$ & $\ldots$ \\
5 & $\ldots$ & $\ldots$ \\
$\ldots$ & $\ldots$ & $\ldots$ \\
10 & $\ldots$ & $\ldots$ \\
\hline
\end{tabular}

Table 5 Description of Interviewees

\begin{tabular}{|c|c|c|}
\hline Main entrepreneurial activities observed & Interviewees & $\begin{array}{l}\text { Relationship level } \\
\text { involvement }\end{array}$ \\
\hline Collaboration with industry through joint research projects & $\begin{array}{l}\text { All } \\
(\mathrm{A} 1-\mathrm{A} 12)\end{array}$ & $\begin{array}{l}\text { Project level, } \\
\text { individual level }\end{array}$ \\
\hline $\begin{array}{l}\text { Acquiring research funding (grants) from government, non-govern- } \\
\text { mental or international bodies (with or without collaboration with } \\
\text { industry) }\end{array}$ & $\begin{array}{l}\text { All } \\
(\mathrm{A} 1-\mathrm{A} 12)\end{array}$ & $\begin{array}{l}\text { Project level, } \\
\text { individual level }\end{array}$ \\
\hline $\begin{array}{l}\text { Inter-academic collaborations (with or without industry involve- } \\
\text { ment) }\end{array}$ & $\begin{array}{l}\text { All } \\
(\mathrm{A} 1-\mathrm{A} 12)\end{array}$ & $\begin{array}{l}\text { Project level, } \\
\text { individual level }\end{array}$ \\
\hline $\begin{array}{l}\text { Contributing to the formation of one or more new spin-off compa- } \\
\text { nies }\end{array}$ & A4 & Individual Level \\
\hline $\begin{array}{l}\text { The formation of joint venture/(s) privately through collaborating } \\
\text { with industry links }\end{array}$ & A4 & Individual Level \\
\hline $\begin{array}{l}\text { Research-based consultancy privately (but without forming a com- } \\
\text { pany) }\end{array}$ & $\begin{array}{l}\text { All } \\
(\mathrm{A} 1-\mathrm{A} 12)\end{array}$ & Individual level \\
\hline
\end{tabular}




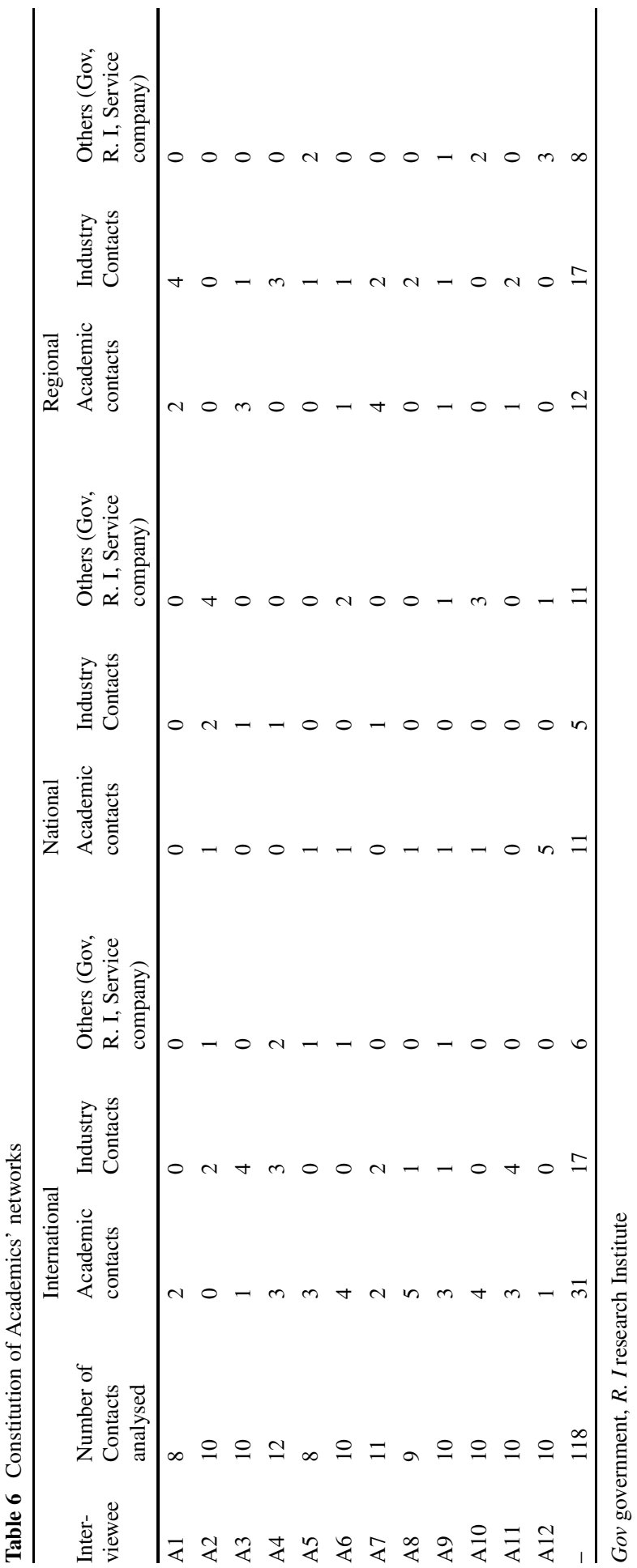




\section{References}

Agrawal AK (2001) University-to-industry knowledge transfer: literature review and unanswered questions. Int J Management Reviews 3:285-302

Ahoba-Sam R (2019) Why do academics engage locally? Insights from the University of Stavanger. Reg Stud Reg Sci 6:250-264

Almeida P, Kogut B (1999) Localization of knowledge and the mobility of engineers in regional networks. Manage Sci 45:905. https://doi.org/10.1287/mnsc.45.7.905

Alpaydin UAR, Atta Owusu K, Moghadam-Saman S (2018) The role of universities in innovation and regional development: the case of Rogaland Region. RUNIN Working Paper Series; Vol. 2018, No. 05

Altmann A, Ebersberger B (2013) Universities in change: a brief introduction. In: Managing higher education institutions in the age of globalization. Springer, New York, pp 1-8

Andersson S (2011) International entrepreneurship, born globals and the theory of effectuation. J Small Bus Enterp Dev 18:627-643

Andersson S, Evers N (2015) International opportunity recognition in international new ventures-a dynamic managerial capabilities perspective. J Int Entrep 13:260-276

Borgatti SP, Everett MG, Johnson JC (2013) Analyzing social networks. SAGE, London

Charles D (2006) Universities as key knowledge infrastructures in regional innovation systems. Innov Eur J Soc Sci Res 19:117-130

Christopherson S, Clark J (2010) Limits to 'the learning region': what university-centered economic development can (and cannot) do to create knowledge-based regional economies. Local Econ 25:120-130

Clark BR (1998) Creating entrepreneurial universities: organizational pathways of transformation. Issues in higher education. Pergamon Press, New York

Engel Y, Kaandorp M, Elfring T (2017) Toward a dynamic process model of entrepreneurial networking under uncertainty. J Bus Ventur 32:35-51

Etzkowitz H (2003) Research groups as 'quasi-firms': the invention of the entrepreneurial university. Res Policy 32:109-121

Fernández-Pérez V, Alonso-Galicia PE, Rodríquez-Ariza L, Fuentes-Fuentes MDM (2015) Professional and personal social networks: a bridge to entrepreneurship for academics? Eur Manag J 33:37-47

Foss L, Gibson D (2015) The entrepreneurial university: context and institutional change

Galkina T, Chetty S (2015) Effectuation and networking of internationalizing SMes. Manag Int Rev 55:647-676

Goddard JB, Chatterton P (1999) Regional development agencies and the knowledge economy: harnessing the potential of universities. Environ Plann C Gov Policy 17:685-699

Granovetter MS (1973) The strength of weak ties. Am J Sociol 78:1360-1380

Gulbrandsen M, Slipersæter S (2007) The third mission and the entrepreneurial university model. In: Universities and strategic knowledge creation, vol 4. Edward Elgar, Great Britain

Gunasekara C (2006) Reframing the role of universities in the development of regional innovation systems. J Technol Transfer 31:101-113

Hammarberg K, Kirkman M, De Lacey S (2016) Qualitative research methods: when to use them and how to judge them. Hum Reprod 31:498-501

Hannibal M, Evers N, Servais P (2016) Opportunity recognition and international new venture creation in university spin-offs - Cases from Denmark and Ireland. J Int Entrep 14:345-372

Hayek FA (1945) The use of knowledge in society. Am Econ Rev 35:519-530

Henry N, Pinch S (2000) Spatialising knowledge: placing the knowledge community of Motor Sport Valley. Geoforum 31:191-208

Jain S, George G, Maltarich M (2009) Academics or entrepreneurs? Investigating role identity modification of university scientists involved in commercialization activity. Res Policy 38:922-935 (Research Collection Lee Kong Chian School Of Business)

Klofsten M, Jones-Evans D (2000) Comparing academic entrepreneurship in europe-the case of Sweden and Ireland. Small Bus Econ 14:299-309

Lam A (2007) Knowledge networks and careers: academic scientists in industry-university links. J Management Studies 44:993-1016

Lowrie A, McKnight PJ (2004) Academic research networks: a key to enhancing scholarly standing. Eur Manag J 22:345-360

Mahroum S (2000) Scientists and global spaces. Technol Soc 22:513-523

March JG (1991) Exploration and exploitation in organizational learning. Organ Sci 2:71-87 
Meyer M (2003) Academic entrepreneurs or entrepreneurial academics? Research-based ventures and public support mechanisms. R D Manage 33:107-115

Miller K, Alexander A, Cunningham J, Albats E (2018) Entrepreneurial academics and academic entrepreneurs: a systematic literature review. Int J Technol Manag 77:9

Nonaka I (1994) A dynamic theory of organizational knowledge creation. Organ Sci 5:14-37

Nyeko K, Sing N (2015) Academic Entrepreneurs and Entrepreneurial Academics: Are They the Same. Int J Soc Sci Humanity 5(12):1050-1055

Pataraia N, Margaryan A, Falconer I, Littlejohn A (2014) Discovering academics' key learning connections: An ego-centric network approach to analysing learning about teaching. J Workplace Learn 26:56-72

Pataraia N, Margaryan A, Falconer I, Littlejohn A (2015) How and what do academics learn through their personal networks. J Furth High Educ 39:336-357

Perkmann M, Walsh K (2007) University-industry relationships and open innovation: towards a research agenda. Int J Management Reviews 9:259-280

Perkmann M, King Z, Pavelin S (2011) Engaging excellence? Effects of faculty quality on university engagement with industry. Res Policy 40:539-552

Perkmann M, Tartari V, McKelvey M, Autio E, Broström A, D’Este P, Fini R, Geuna A, Grimaldi R, Hughes A, Krabel S, Kitson M, Llerena P, Lissoni F, Salter A, Sobrero M (2013) Academic engagement and commercialisation: a review of the literature on university-industry relations. Res Policy 42:423-442

Plewa C, Korff N, Johnson C, MacPherson G, Baaken T, Rampersad GC (2013) The evolution of university-industry linkages-A framework. J Eng Technol Manag 30:21-44

Prashantham S, Kumar K, Bhagavatula S, Sarasvathy SD (2019) Effectuation, network-building and internationalisation speed. Int Small Bus J 37:3-21

Ramos-Vielba I, Sánchez-Barrioluengo M, Woolley R (2016) Scientific research groups' cooperation with firms and government agencies: motivations and barriers. J Technol Transf 41:558-585

Sarasvathy S (2001) Causation and effectuation: toward a theoretical shift from economic inevitability to entrepreneurial contingency. Acad Manage Rev 26:243-263

Sarasvathy S (2005) What makes entrepreneurs entrepreneurial? University of Virginia-Darden School of Business, Virginia

Sarasvathy SD, Dew N (2011) Without judgment: an empirically-based entrepreneurial theory of the firm. Rev Austrian Econ 26:277-296

Sataøen HL (2018) Transforming the "third mission" in Norwegian higher education institutions: a boundary object theory approach. Scand J Educ Res 62:52-67

Schreier C, Senn A (2018) Western expatraits building networks in Asia - an analysis based on causation vs. effectuation theory. ABAC J 38:116-132

Shaw JK, Allison J (1999) The intersection of the learning region and local and regional economic development: analysing the role of higher education. Reg Stud 33:896-902

Siegel DS, Veugelers R, Wright M (2007) Technology transfer offices and commercialization of university intellectual property: performance and policy implications. Oxf Rev Econ Policy 23:640-660

Sternberg R (2000) Innovation networks and regional development-evidence from the European Regional Innovation Survey (ERIS): theoretical concepts, methodological approach, empirical basis and introduction to the theme issue. Eur Plan Stud 8:389-407

Stuck J, Broekel T, Revilla Diez J (2016) Network structures in regional innovation systems. Eur Plan Stud 24:423-442

Trippl M (2013) Scientific mobility and knowledge transfer at the interregional and Intraregional level. Reg Stud 47:1653-1667

Trippl M, Sinozic T, Smith HL (2012) The "third mission" of universities and the region: Comparing the UK,Sweden and Austria. Paper at the 52nd European Congress of the RSAI, 21st August 2012 Bratislava, Slovakia. http://www-sre.wu.ac.at/ersa/ersaconfs/ersa12/e120821aFinal00063.pdf. Accessed 01.09.2019

Venkataraman S (1997) The distinctive domain of entrepreneurship research. In: Katz JA (ed) Advances in entrepreneurship, firm emergence and growth, vol 3. JAI Press, Greenwich

Vorley T, Nelles J (2009) Building entrepreneurial architectures: a conceptual interpretation of the third mission. Policy Futur Educ 7:284-296

Wilson JR (2014) Essentials of business research, a guide to doing you research project. SAGE, London

Yin RK (1984) Case study research: design and methods. SAGE, London

Yin RK (2002) Case study research-design and methods. SAGE, London

Publisher's Note Springer Nature remains neutral with regard to jurisdictional claims in published maps and institutional affiliations. 